\title{
PSYCHOLOGICAL CORRELATES OF EMOTIONAL AND PERSONAL WELL-BEING
}

Galina Glotova. Leading researcher of Psychological Department, Lomonosov Moscow State University, Russia

The study of human well-being has a long history. Since the ancient times, this subject has been reviewed from the angle of two research traditions: the hedonic and the eudaimonic one (Lopez \& Snyder, 2009). Nowadays, these traditions are represented by the constructs of "subjective well-being" and "psychological well-being" "Subjective well-being" is "psychologice "somprised of such rather more integral constructs as satisfaction with life" and "balance of positive and negative affects" (Diener \& Suh, 1997), whereas "psychological well-being" includes six integral constructs ("self-acceptance", "personal growth", "purpose in life", "positive relations with others", "environmental mastery", "autonomy") (Ryff, 1989). Thus, two important oppositions emerge from the study of human wellbeing: a) opposition of subjective (emotional) to psybeing: a) opposition chological (personal) well-being; b) opposition of the positive to the negative affect. These two parameters construct: "emotional and personal well-being" (Glotova \& Karapetyan, 2009), which includes two positive components: "emotional" (A), and "personal" (B) and one negative component $(C)$. The "Self-Assessment of Emotional and Personal Well-being" research tool was developed on the basis of this constuct.

The objective was to explore the psychological correlates of self-assessment of emotional and personal well-being. The "Self-Assessment of Emotional and Personal Well-being" research tool) (Glotova \& Karapetyan, 2009) was offered to adults aged 18-65. The participants had to assess themselves on a seven-point scale, using the following parameters: "happy", "lucky", "optimist" (positive emotional component A); "successful", "competent", "reliable" (positive personal component B); "pessimistic", "unhappy", "envious" (negative component C) (Study 1, $n=2229$ ). The results for each of the nine parameters were analysed and the general index of self-assessment of emotional and personal dex of self-assessment of emotional and personal well-being was calculated using this formula: A+B-C. The following research tools were also used: Myers-
Briggs Type Indicator (MBTI, F; El scale) (Briggs Myers \& McCaulley, 1985) (Study 2, n=857); Rog-

References:
Briggs Myers, I., \& McCaulley M. (1985) Manual: A Guide to the Development Press. Diener, E., \& Suh, E. (1997). Measuring quality of life: Economic, social,
and subjective indicators. Social Indicators Research, 40(1-2), 189-216. doi
ers-Diamond Test of Social-Psychological Adaptation (SPA) (Raygorodsky, 2000) (Study 3, n=1201).

Study 1 was conducted using the "Self-Assessment of Emotional and Personal Well-being" re search technique for adults aged 18-65 ( $n=2229)$. The descriptive statistics were obt ained for each of the nine parameters and for the general in dex of self-assessment of emotional and persona well-being $(A+B-C)$. The scores for the general index ranged between -9.00 to $39.00, M=23.67$.

Study 2 explored the Spearman's correlations be ween the parameters and the index of self-assessment of emotional and personal well-being and the continuous "extroversion-introversion" (EI) scale of the Myers-Briggs (MBTI, F) research tool (the high scores on the El scale correlate with introversion, and the low scores correlate with extraversion). The Spearman's correlation coefficient of the general in $\operatorname{dex} A+B-C$ with the El scale of the MBTI, F research tool, is statistically significant $(r=-0.280 ; p<0.001)$.

Table 1. Correlations between the parameters of "Self-Assessment of Emotional and Personal Well-being" research tool and the scores of the continuous scale El (MBTI, F) ( $n=857$ )

\begin{tabular}{|l|l|l|l|}
\hline A & El & B & El \\
\hline Happy & $-0.206^{* * *}$ & Successful & $-0.198^{* * *}$ \\
\hline Lucky & $-0.218^{* * *}$ & Competent & $-0.162^{\star * *}$ \\
\hline Optimist & $-0.248^{* * *}$ & Reliable & $-0.172^{* * *}$ \\
\hline C & El & Note: & \\
\hline Pessimistic & $0.127^{* * *}$ & ${ }^{* * *} p<0.001$ & \\
\hline Unhappy & 0.053 & \multirow{2}{*}{$p<0.05$} & \\
\hline Envious & $0.083^{*}$ & & \\
\hline
\end{tabular}

As you can see in Table 1 , all of the six positive parameters of the "Self-Assessment of Emotional and Personal Well-being" research technique showed negative correlation (at $p \leq 0,001$ ) with the El scale, i.e. with introversion. The negative parameters, on the contrary, had shown positive correlation with introversion.

The correlations between the higher rates obtained using the "Self-Assessment of Emotional and Person al Well-being" research tool and extraversion is iden-

Glotova, G. A. \& Karapetyan L. V. (2009). Osobennosti predstavlenii o sebe u
razlichnyh grupp ispytuemyh [Specificity of self-perception among different groups razlichnyh grupp ispytuemyh [Specificitity of self-perception among different groups
of testees]. Vestnik Uralskogo Federalnogo Universiteta. Seriya 1. Problemy ob-
razovaniya, nauki l kutury [The Ural Federal Iniversity Bulletin, Series 1 . Issues of education, science and culture], 1/2(62), 52-60. Keyes, C.L.M. Shmookin, D., \& Ryff, C.D. (2002). Optimizing well-being: The empiricale en-
counter of two traditions. Joumal of Personality and Social Psychology Vol $82(6)$ 1007-1022 tified and between the lower rates and introversion corresponds to the results obtained using other constructs of well-being and other research tools. Thus in the research by Schmutte \& Ryff (1997), five out of the six parameters of "psychological well-being", as described in the Psychological Well-Being Inventory (Ryff, 1989) ("self-acceptance", "personal growth", "purpose in life", "positive relations with others", "environmental mastery") showed statistically significan correlation with "extraversion" $(E)$, obtained using the methodology of NEO Five-Factor Inventory (Costa \& McCrae, 1992). The research of Keyes, Shmotkin, \& Ryff (2002) showed that the probability of optimal wellbeing (high levels both of Subjective well-being and Psychological well-being) increased together with in-

In Study 3, multiple correlations were revealed, us ing Spearman's correlation analysis, between the nine parameters and the general index of self-assessment of emotional and personal well-being and the integra indicators of the Rogers-Diamond Test of Social-Psychological Adaptation (SPA) research tool $(n=1201)$. Table 2. Correlations between the general index of the "Self-Assessment of Emotional and Personal Well-being" research tool and the integral indicators of the Rogers-Diamond Test of Social-Psychological Adaptation (SPA) research tool $(n=1201)$

\begin{tabular}{|l|l|l|}
\hline $\begin{array}{l}\text { Integral indicators } \\
\text { (SPA) }\end{array}$ & $\begin{array}{l}\text { Spearman's correla- } \\
\text { tion coefficients }\end{array}$ & $p$ \\
\hline Adaptation & 0.422 & 0.001 \\
\hline Self-acceptance & 0.401 & 0.001 \\
\hline Acceptance of others & 0.360 & 0.001 \\
\hline Emotional comfort & 0.428 & 0.001 \\
\hline Internality & 0.349 & 0.001 \\
\hline Need to dominate & 0.244 & 0.001 \\
\hline
\end{tabular}

Using Spearman's correlation analysis of the nin parameters of the "Self-Assessment of Emotional and Personal Well-being" research tool with the integra coefficients of the SPA $(n=1201) 52$ out of 54 possible statistically significant correlations were obtained and, moreover, all 52 had a high level of significance $(p<0.001)$. The positive parameters "happy", "lucky",

Lopez, S. J., \& Snyder, C. R. (2009). Oxford handbook of positive
psychology. New York: Oxford University Press. doi: 10.1093/oxfordhb/9780195187243.001.000 Raygorodsky D. Ya. (Ed.). (2000). Prakticheskaja psihodiagnostika. Metodik
testy. [Practical psychodiagnostics. Techniques and tests]. Samara: BAKHRAitesty. . Practical ps.
KH-M, p. $457-465$. "optimist", "successful" and "competent" revealed six out of six possible significant positive correlations with the integral coefficients of SPA, and the parameter "reliable" revealed five significant positive correlations. The negative parameters "pessimistic" and "unhappy" revealed six significant negative correlations, out of the possible six, with the integral coefficients of SPA, and the parameter "envious" demonstrated five significant negative correlations out of six

The correlations between the nine parameters and the general index of "Self-Assessment of Emotional and Personal Well-being" research tool and the integral indicators of the SPA are of interest to us because the six integral indicators of SPA represent the six integral constructs constituting the content of the generalized construct "social and psychological adaptation". These integral SPA constructs have certain similarities with the integral constructs that constitute the generalized constructs "subjective wellbeing" and "psychological well-being". The integra indicator "emotional comfort" is similar in meaning to "balance of positive and negative affects", which is used in the study of "subjective well-being". The integral indicator "self-acceptance" in the SPA research technique corresponds to the factor of "self-acceptance" in the theory of Ryff. Part of the remaining integral indicators of the SPA research tool, although named differently, have a certain semantic similarity to the factors of "psychological well-being" identified by Ryff. Thus the data obtained indicate that the generalized construct of "social and psychological adaptation" comprises such integral constructs which by their nature are associated with an individual's perception of various aspects of well-being - whether subjective, psychological or emotional and personal.

Conclusion: For people with high scores of positive parameters and a high general index of self-assessment of emotional and personal well-being the following are typical: extroversion, high scores of adaptation, self-acceptance, and acceptance of others, need to dominate.

Ryff, C.D. (1989). Happiness is everything, or is it? Explorations on the mean-
of psychological wellbeing. Joumal of Personality and Social Psychology, $57(6)$, ing of psychological wellbeing. Joumal of Personality and Social Psychology, $5 /(6)$
$1069-1081$. Schmutte, P.S. \& Ryff, C.D. (1997). Personality and well-being: Reexamining meth-
ods and meanings. Journal of Personality and Social Psychology, Vol 73(3), 549-559, 